\title{
Investigation of urinary proteins in multiple myeloma by means of salting-out analysis
}

The proteins excreted in urine by patients suffering from multiple myeloma (Kahler's disease) have already been investigated by means of electrophoresis and ultracentrifugation. However, these methods cannot give a very detailed picture of the composition of these proteins.

We presumed that the very sensitive salting-out analysis as developed by DERRIEN ${ }^{1}$ would offer a better means of characterizing the urinary proteins.
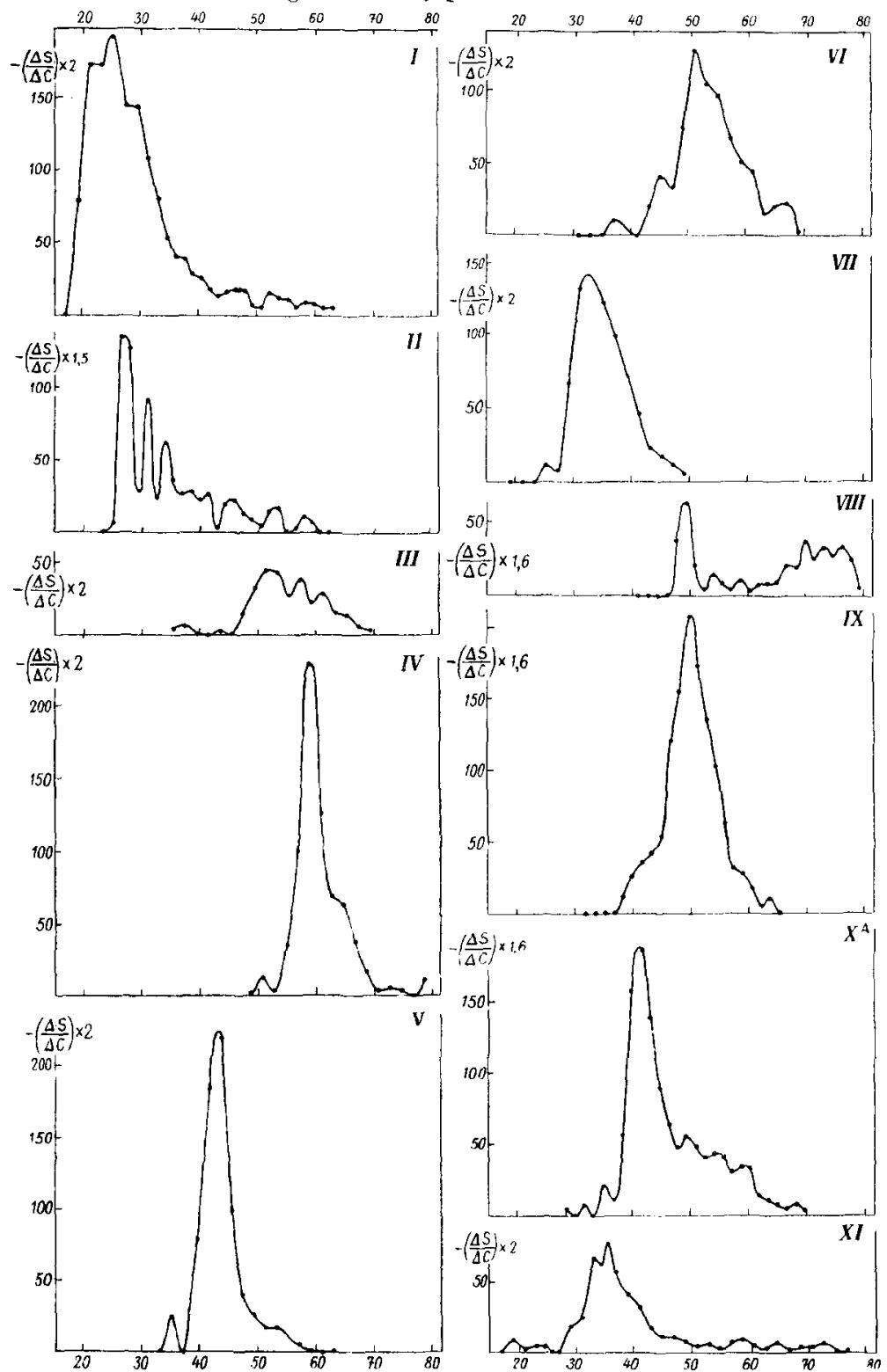

Fig. 1. Salting-out diagrams of urinary proteins. Derived curves. Abscissa: salt concentration in \% $(\mathrm{v} / \mathrm{v}) 3.5 \mathrm{M}$ phosphate buffer, $\mathrm{pH}$ 6.5. Ordinate: change in amount of protein nitrogen in solution from point to point. $\Delta \mathrm{C}=$ interval between two successive salt concentrations $=1.6$ or $2 \%(\mathrm{v} / \mathrm{v})$ $3.5 M$ phosphate. Limit of precipitation of globulins: 66 to $67 \%(\mathrm{v} / \mathrm{v}) 3.5 M$ phosphate. 
In the course of an extensive investigation of urinary and serum proteins in multiple myeloma ${ }^{2}$ proteins were isolated from the urine of eleven patients by precipitation with ammonium sulfate, dissolved in water and dialyzed free of ammonium sulfate against vater. This precipitation, dissolution and dialysis was repeated 2 to 3 times to purify the protein, and finally the protein solution was dialyzed against $0.02 M \mathrm{KCl}$.

The protein solutions thus obtained were salted out with a 3.5 molar potassium phosphate buffer, $\mathrm{pH}$ 6.5. The amount of protein remaining in solution was estimated by micro-Kjeldahl determination of protein nitrogen in the filtrates. The so-called "drrived" salting-out curves obtained in each case are assembled in Fig. 1 .

The great disparity of the diagrams is seen at a glance. Some proteins are fairly homogeneous for the greater part (nos. IV, V, VII, IX), others are markedly heterogeneous. The solubilities also vary distinctly. As to the degree of homogeneity, it is not possible to draw a distinction between the group of proteins with Bence-Jones characteristics (in our case, nos. II, IV, VII, XI and part of no. VI) and those lacking the property of coagulating at 50 to $55^{\circ} \mathrm{C}$ and redissolving upon further heating to $100^{\circ} \mathrm{C}$. In both groups of proteins we find examples of fairly homogeneous and of markedly heterogeneous composition. The same applies to the solubility of the main component of each protein. It cannot be said that there is always one Bence-Jones protein, characterized by a certain solubility.

Thus, the sensitive salting-out analysis, which gives such detailed pictures of the composition of protein mixtures, serves to emphasize the diversity and complexity of the proteins excreted in urine in multiple myeloma.

The skilled technical assistance of Miss A. G. ZWART is gratefully acknowledged.

\author{
Laboratory for Physiological Chemistry, The University, \\ Utrecht (Nethevlands) \\ O. J. TEN THIJE
}

Elizabeth P. Steyn-Parvé

1 Y. DERRIEN, Biochim. Biophys. Acta, 8 (I952) 63 I.

2 O. J. TEN Thije, Thesis, Utrecht, I954.

Received February 23rd, 1955

\title{
The formation of nucleoside triphosphate from inosine diphosphate in yeast
}

Recent work has demonstrated the existence of several enzymes catalysing the phosphorylation of nucleoside mono- and diphosphates ${ }^{1-4}$. Two of these, the adenyl kinase of KALCKAR ${ }^{1}$, and the uridyl kinase of I.IEBERMAN et al. ${ }^{3}$, catalyse the dismutation of two molecules of nucleoside diphosphate to one molecule of nucleoside monophosphate plus one molecule of nucleoside triphosphate. In this communication there is described evidence for the existence in yeast extracts of an enzyme catalysing a similar dismutation of two molecules of inosine diphosphate.

The sources of the enzyme were commercial samples of baker's and brewer's yeast *. The yeast was rapidly chilled in solid carbon dioxide and thawed, and then extracted for 5 minutes at $60^{\circ} \mathrm{C}$ with 2 volumes of $\mathrm{N} / \mathrm{I}$ O $\mathrm{HCl}$. The preparation was centrifuged at $20,000 \mathrm{~g}$ for Io minutes and brought to $\mathrm{pH} 6$. This preparation (the yeast enzyme) was stable for two to three days at $0^{\circ} \mathrm{C}$, but occasionally lost activity more rapidly. Nucleoside phosphates present in the extract were removed by treatment with Dowex-I.

The assay system chosen to trap nucleoside triphosphate was phosphofructokinase, which has been shown by LING AND LARDY 5 to react with ATP, ITP and UTP at almost equal rates, a finding which was confirmed here. Fructose-1 :6-diphosphate was estimated spectrophotometrically by measuring the oxidation of DPNH following conversion to triose phosphate according to the method of RACKER ${ }^{6}$. The complete series of reactions is:

$$
\begin{array}{lr}
\text { 2 IDP } \rightarrow \text { ITP }+ \text { IMP } & (\mathrm{I}) \\
\text { glucose-6-phosphate } \rightarrow \text { fructose-6-phosphate } & (2) \\
\text { fructose-6-phosphate }+ \text { ITP } \rightarrow \text { fructose-I }: 6 \text {-diphosphate }+ \text { IDP } & (3) \\
\text { fructose-I :6-diphosphate } \rightarrow \text { dihydroxyacetone phosphate + 3-phosphogiyceraldehyde }(4) \\
\text { 3-phosphoglyceraldehyde } \rightarrow \text { dihydroxyacetone phosphate } \\
\text { dihydroxyacetone phosphate + DPNH } \rightarrow \text { glycerol-3-phosphate }+ \text { DPN }
\end{array}
$$

DPNH free from nucleotide impurities was prepared by the method of OHLMEYER ${ }^{7}$. Table I gives the results of a typical experiment demonstrating the necessity for the simultaneous presence

* Among yeasts from which active enzyme preparations were obtained were those from the Compressed Yeast Co., of Sidney; Nycander \& Co., Melbourne; and the Richmond Brewing Co., Melbourne. In several other brewer's yeasts tested the enzyme could not be demonstrated. Grateful acknowledgement is made to all companies which generously supplied samples of their cultures. 